\title{
Sensory profile of sanjai balado chips in West Sumatra
}

\author{
Mimi Nurminah $^{1,{ }^{*}}$ and Nurmia Novianti ${ }^{1}$ \\ ${ }^{1}$ Department of Food Science and Technology, Faculty of Agriculture, Universitas Sumatera Utara, \\ 20155, Medan, Indonesia.
}

\begin{abstract}
Sanjai Balado chips are famous local snack originated from West Sumatra, Indonesia. Sanjai balado chips consist of cassava chips coated with local chili paste known as sambal balado. Our concern was looking for the sensory attributes of sanjai balado chips before the intensity of each attributes be evaluated. The analysis was carried out using 1proportion test to identified the attributes based on the data of the direct survey with checklist form toward 25 respondents of people from west Sumatra who are involved in the production of sanjai balado. The final result of the survey shows there are 16 sensory attributes out of 27 sensory attributes that have a significant effect on the perception of Sanjai Balado chips by respondents in the survey. The attributes are red color, red orange color, sweet taste, savory taste, sweet aroma, the aroma of local chili paste, the aroma of cassava, fried onion aroma, crispy texture, hard texture, spicy mouthfeel, oily mouthfeel, sticky mouthfeel, savory flavor, chili sauce flavor, and oily afterfeel.
\end{abstract}

\section{Introduction}

West Sumatra Province is one of the tourist destinations that can be visited by tourists because its natural beauty and the diversity of Minangkabau culture. The high number of tourists visiting makes business opportunities in West Sumatra higher, especially the producer of Sanjai Balado chips.

Sanjai balado chips are one of the local snacks from West Sumatra and it is consist of cassava chips coated with local chili paste known as sambal balado. Therefore, it has a distinctive taste and aroma characteristics [1]. In the manufacturing stage of Sanjai balado chips, there are two main stages the first is the manufacture of cassava chips and then manufacture of sambal balado as a sauce. The processing stages consist of cassava peeling, slicing, washing, slicing, frying, and adding seasoning nto the cassava chips, namely sambal balado [2].

In determining the sensory attributes, the aim is to find out the basic characteristics experienced by the panelists, both simple and complex characteristics, before evaluating the sensory attributes [3]. Sensory evaluation is a method that is carried out scientifically aimed

\footnotetext{
* Corresponding author: miminurminah@usu.ac.id
} 
at measuring, analyzing, and interpreting the sensory properties or characteristics of a food product using the five human senses, namely the senses of hearing, sight, smell, touch, and taste, both basic sensations or complex sensations to determine sensory quality of a product or product development [4]. In this study, a preliminary survey was conducted to determine the sensory attributes of Sanjai Balado chips before evaluating the intensity of each sensory attribute

\section{Methods}

The method used in this study was obtained by conducting two stages direct survey. In the first stage of the survey was conducted to 127 respondents from West Sumatra and NonWest Sumatra with the aim to know how was the public's perception of Sanjai Balado chips. The next step is the process of collecting sensory attribute vocabulary and carry out literature study on the sensory attribute vocabulary that has been collected through the previous questionnaire sheet.

The second direct survey is conducted to get more specific sensory attributes and to validate whether or not the sensory attributes are part of sanjai balado chips characteristics based the preference of 25 native West Sumatran respondents who are involved in the production of sanjai balado through the checklist sheet. In this research, respondents can check the sensory attributes that they felt exists in the Sanjai Balado chip products they have tasted, after that the data obtained from the preliminary research checklist sheet is tested using the 1-Proportion Test on the Minitab 16 software [5].

\section{Result and discussion}

In this preliminary survey toward 127 respondents, the results obtained were 127 respondents from West Sumatra as many as 77 respondents $(61 \%)$ and Non-West Sumatra $(39 \%)$, where from In this survey, 42 respondents $(33 \%)$ were male and 85 respondents $(67 \%)$ were female. The overall age range of respondents in the survey is between 19-56 years. The result shows that 123 respondents $(97 \%)$ answered that they had ever consumed Sanjai Balado chips, while 4 respondents $(3 \%)$ answered that they had never consumed Sanjai Balado chips.

This result is supported by the fact that Sanjai Balado chips are well known among society. In addition, it is found that 116 respondents (91\%) answered that they liked Sanjai Balado chips while 11 respondents $(9 \%)$ claimed that the chips are not on their favor.. Most of the respondents stated that they liked Sanjai Balado chips because of the spicy sensation and sweet flavor. Moreover, those who declared that they did not like Sanjai Balado chips stated that the chips were too sweet and had a spicy sensation as well as a slightly sticky texture. These different respondents' perceptions of Sanjai Balado chips are influenced by the food habits of different people that affect how individuals give perceptions, impressions, and preferences for food, including components of various flavors and flavors [6].

Based on the data obtained from survey toward 25 native West Sumatran respondents who are involved in the production of sanjai balado through the checklist sheet and analyzed by 1-proportion test, the results shows that for the color attribute group on the Sanjai Balado chips, it was found that the red color was chosen by 25 respondents and it presented significantly different results ( $p$ - value $<0.05$ ). 
Table 1. Result 1-proportion test of Sanjai Balado Chips

\begin{tabular}{|c|c|c|c|}
\hline No. & Attribute & Respondents & p-value \\
\hline 1. & Red color & 25 & 0,000 \\
\hline 2. & Orange color & 5 & 0,652 \\
\hline 3. & Orangered color & 19 & 0,000 \\
\hline 4. & Reddish brown color & 4 & 0,363 \\
\hline 5. & Sweet taste & 25 & 0,000 \\
\hline 6. & Savory taste & 23 & 0,000 \\
\hline 7. & Sour taste & 11 & 0,062 \\
\hline 8. & Salty taste & 3 & 0,168 \\
\hline 9. & Sweet aroma & 21 & 0,000 \\
\hline 10. & Sour aroma & 1 & 0,355 \\
\hline 11. & Aroma of local chili paste (sambal) & 25 & 0,000 \\
\hline 12. & Typical Aroma of cassava & 21 & 0,000 \\
\hline 13. & Chili aroma & 5 & 0,187 \\
\hline 14. & Coconut oil aroma & 5 & 0,187 \\
\hline 15. & Aroma of fried onion & 10 & 0,000 \\
\hline 16. & Spices aroma & 3 & 1,000 \\
\hline 17. & Caramel aroma & 14 & 0,187 \\
\hline 18. & Crispy texture & 25 & 0,000 \\
\hline 19. & Hard texture & 15 & 0,009 \\
\hline 20. & Tough texture & 5 & 0,205 \\
\hline 21. & Oily Mouthfeel & 22 & 0,000 \\
\hline 22. & Spicy Mouthfeel & 23 & 0,000 \\
\hline 23. & Sticky Mouthfeel & 23 & 0,000 \\
\hline 24. & Savory flavor & 21 & 0,000 \\
\hline 25. & The flavor of local chili paste (sambal) & 23 & 0,000 \\
\hline 26. & Spicy flavor & 6 & 0,401 \\
\hline 27. & Oily afterfeel & 18 & 0,043 \\
\hline
\end{tabular}

In addition, 19 respondents from 25 respondents also chose the color red and orange which indicated significantly different results. This shows that the attributes of red and orange red have a considerable effect on the perception of the product of Sanjai Balado chips by respondents. The identity of a product can be seen from the color impression that is aimed to recognize the product; it also functions as the component to attract consumers [7].

Based on the group of taste attribute data, it is found that 25 respondents chose the sweet taste and 23 respondents chose the savory taste which showed significantly different results ( $\mathrm{p}$-value $<0.05$ ). While the sour taste was only chosen by 11 respondents and only 3 respondents chose the salty taste so that the results were not significantly different ( $p$-value 
$>0.05)$. This proves that sweet and savory tastes dominate over sour and salty tastes based on consumer perception. There are five basic tastes that can be recognized by the human senses, namely bitter, salty, sour, sweet, and umami, this depends on the product or compound tasted by the human senses [8].

In the aroma attribute group, the data obtained were 21 respondents who chose a sweet aroma and the aroma of local chili paste (sambal), 21 respondents who chose the typical aroma of cassava, 10 respondents chose the aroma of fried onions, 14 respondents chose the caramel aroma which showed that the aroma attribute group was significantly different ( $\mathrm{p}$ value $<0.05$ ) that these aromas affect the respondent's perception of the product of Sanjai Balado chips. While 1 respondent chose the sour aroma, 5 respondents chose the chili aroma, 5 respondents chose the coconut oil aroma, and 3 respondents chose the spice aroma so that the results were not significantly different ( $p$-value $>0.05$ ). The classification of aroma received by humans usually comes from the odor associated with a particular product or compound that has been recognized or common. Thus, the components that make up a product will affect the aroma or smell of the product [8].

Based on the data from the texture attribute group, it is found that 25 respondents chose a crunchy texture and 15 respondents chose a hard texture while 5 respondents chose a tough texture. This shows that the crunchy and hard texture is more dominant in influencing consumer perceptions of Sanjai Balado chips. Meanwhile, the mouthfeel category showed that 22 respondents chose oily mouthfeel and 23 respondents chose spicy mouthfeel as well as sticky mouthfeel was also chosen by 23 respondents, thus the three mouthfeels showed significantly different results ( $\mathrm{p}$-value $<0.05$ ). Sensation or mouthfeel is a taste sensation obtained through the trigeminal nerve which shows certain sensations when tasting food, for example, a spicy sensation from chili peppers, or a cold sensation from sorbitol [8].

In the flavor category, it was found that as many as 21 respondents chose the savory flavor and as many as 23 respondents chose the local chili paste (sambal balado) flavor so that after the results obtained were significantly different ( $p$-value $<0.05$ ). Meanwhile, as many as 6 respondents chose the spice flavor. In oily afterfeel, 18 respondents chose oily afterfeel so that it showed significantly different results ( $p$-value $<0.05$ ). Flavor is a characteristic that is felt through taste receptors in the mouth and aroma receptors in the nose that make certain characteristics or sensations [9]. Mouthfeel is a sensation that can be felt by human tongue while tasting a product, the sensation can be felt when tasting or after tasting a product.

\section{Conclusion}

The final result of the survey shows there are 16 sensory attributes out of 27 sensory attributes that have a significant effect on the perception of Sanjai Balado chips by respondents in the mini survey. The attributes are red color, red orange color, sweet taste, savory taste, sweet aroma, the aroma of local chili paste, the aroma of cassava, fried onion aroma, crispy texture, hard texture, spicy mouthfeel, oily mouthfeel, sticky mouthfeel, savory flavor, chili sauce flavor, and oily afterfeel. Therefore, these attribute will represent the consumer's perception of respondents to describe the sensory attributes contained in the product of Sanjai Balado chips.

\section{References}

1. D. I. Harbi, Rahmanelli. Eksistensi industri kerupuk sanjai di kecamatan mandiangin koto selayan. J. Buana. 3. 489-491. (2019) 
2. [BPOM-RI] Badan Pengawas Obat dan Makanan Republik Indonesia. Buku Modul Produksi Pangan untuk Industri Rumah Tangga: Keripik Sanjai. Direktorat Surveilan Dan Penyuluhan Keamanan Pangan, (2017)

3. Hayati, R., A. Marliah, F. Rosit. Sifat kimia dan evaluasi sensori bubuk kopi arabika. J. Flo. 7. 66-75 (2012)

4. L. M. Poste, D. A. Mackie, G. Butler, dan E. Larmond. 2011. Laboratory Methods for Sensory Analysis of Food Canada (2011)

5. P. Suhartin. Profilling atribut sensori produk gudeg dan produk gudeg kaleng dengan metode RATA (Rate-All-That-Apply) (studi kasus: Gudeg Wijilan Bu Lies). Skripsi. Universitas Brawijaya, Malang. (2016)

6. U. Hassanah, D. R. Adawiyah, B. Nurtama. Preferensi dan ambang batas rasa manis dan pahit: pendekatan multikultural dan gender. J Mutu Pangan. 1 1-8. (2014).

7. K. Fibrianto, M. Dwihindarti.. Profiling atribut jamu kunyit asam dan jamu sinom dengan metode rata (Rate-All-that-Apply) pada beberapa kota di Jawa timur. J. Rek Pangan. 10 16-18. (2016).

8. D. Setyaningsih, A. Apriyanto, dan M. P. Sari. Analisis Sensori untuk Industri Pangan dan Agro. IPB Press, Bogor. (2010)

9. N. S. Antara dan M. Wartini. Aroma and Flavor Compounds. Universitas Udayana, Bali. (2013)

10. Ishimaru, Y. Dan H. Matsunami. 2009. Transient receptor potential (TRP) channels and taste sensation. J. Dent. Res.. 88 212-213. (2009) 